\title{
PENGGUNAAN BERBAGAI KONSENTRASI RAGI TERHADAP PERTUMBUHAN SUBKULTUR JARINGAN MANGGIS (Garcinia mangostana L) SECARA IN-VITRO
}

\author{
In Vitro Making Use of Various Yeast Concentration on the Growth Subculture of Mangosteen \\ (Garcinia Mangostana L.) Tissue. \\ ${ }^{* 1}$ Astri Marlina, ${ }^{2}$ Tri Nopsagiarti dan ${ }^{3}$ Jamalludin \\ ${ }^{* 1}$ Prodi Agroteknologi Fakultas Pertanian Universitas Islam Kuantan Singingi \\ E-mail: as3luter@gmail.com \\ 2 Prodi Agroteknologi Fakultas Pertanian Universitas Islam Kuantan Singingi \\ E-mail: trinopsagiarti@uniks.ac.id \\ ${ }^{3}$ Prodi Agroteknologi Fakultas Pertanian Universitas Islam Kuantan Singingi \\ E-mail: jamalludinpku@gmail.com
}

\begin{abstract}
ABSTRAK
Penelitian ini bertujuan untuk mengetahui penggunaan berbagai konsentrasi Ragi terhadap pertumbuhan subkultur jaringan manggis secara In-Vitro. Rancangan yang digunakan adalah Rancangan Acak Lengkap non faktorial yang terdiri dari 4 taraf perlakuan dan 3 kali ulangan, yaitu pemberian Ragi $0 \% ; 4,5 \% ; 9 \%$; dan 13,5\%. Dengan demikian penelitian ini terdiri dari 12 unit percobaan. Setiap unit percobaan terdiri dari 1 botol kultur yang masing-masing berisi 2 eksplan. Parameter yang diamati dalam penelitian ini antara lain : umur muncul tunas (hari), jumlah tunas (minggu), panjang tunas $(\mathrm{cm})$, berat planlet $(\mathrm{mg})$. Data pengamatan dianalisis secara statistik dan uji lanjut menggunakan BNJ pada taraf $5 \%$. Berdasarkan hasil penelitian dapat disimpulkan bahwa pemberian ragi tidak berpengaruh nyata terhadap umur mucul tunas manggis (Garcinia mangostana L.), sedangkan parameter pengamatan lainnya berpengaruh nyata, dimana perlakuan terbaik terdapat pada R2 (Pemberian Konsentrasi Ragi $9 \%$ ) dengan jumlah tunas 2,5 tunas, panjang tunas $2,78 \mathrm{~cm}$, berat planlet $0,25 \mathrm{mg}$.
\end{abstract}

Kata Kunci: Ragi, Manggis, Konsentrasi, In-Vitro.

\begin{abstract}
The aim of this experiment was to investigate in vitro making use of various yeast concentration on the growth subculture of mangosteen (Garcinia mangostana L.) tissue. The research was carried out using the basic method of completely randomyzed design (CRD) non factorial with 4 treatment and 3 replicates, namely the yeast with 0\%; 4,5\%, 9\%, 13,5\%. So there are research consist of 12 units of the experiment. Each and every unit of the experiment consist of 1 culture bottle with 2 explants. The parameters observed in this research were the ages of shoot appear (day), the total of shoots (shoot), the length of shoot $(\mathrm{cm})$, the weight of planlate $(\mathrm{mg})$. The data analyzed with analysis of variance and followed HSD test. The results showed that the use of yeast non significantly toward the age of shoot appear of mangosteen, but the another parameters observation has significantly, and the best result is $R_{2}$ (addition yeast with concentration 9\%) where the total of shoots 2,5 shoot, the length of shoot $2,78 \mathrm{~cm}$, the weight of planlate $0,25 \mathrm{mg}$.
\end{abstract}

Keywords: Yeast, Garcinia mangostana, Concentration, In-Vitro.

\section{PENDAHULUAN}

Manggis (Garcinia mangostana L.) merupakan buah tropis yang memiliki perpaduan warna yang indah dan citarasa yang khas, yakni perpaduan rasa manis, 
asam dan sepat yang tidak dimiliki oleh buah - buahan lainnya. Oleh karena itu, buah manggis sering disebut sebagai buah "eksotik" yang sangat terkenal diluar negeri sehingga mendapat sebutan "Finest fruit of the Tropics", dan "Queen of Fruits" yang memiliki manfaat tinggi antara lain akarnya dapat dijadikan sumber obatobatan, batangnya dapat dijadikan sumber bahan bangunan, buahnya dapat dimakan yang mengandung beragam zat gizi serta vitamin dan dapat dijadikan obat tradisional, serta kulitnya memiliki banyak kandungan antioksidan yang dapat berguna sebagai bahan baku obat-obatan (Pitojo dan Puspita, 2010).

Selain perbanyakan dengan cara generatif, tanaman manggis juga dapat diperbanyak dengan cara vegetatif, walaupun metode perbanyakannya lebih sulit dibandingkan perbanyakan secara generatif, namun dapat menjadi alternatif terbaik karena akan menghasilkan bibit yang sifatnya sama dengan induknya, dan salah satu perbanyakan tanaman secara vegetatif adalah melalui teknik kultur jaringan. Dengan kultur jaringan dapat memperpendek waktu pembibitan, karena keunggulan dari teknik kultur jaringan adalah dapat diperoleh bibit dalam jumlah yang banyak, waktunya lebih singkat dibandingkan dengan perbanyakan secara konvensional, selain itu bibit yang diperoleh juga memiliki sifat yang identik dengan induknya serta terbebas dari hama dan penyakit.

Keberhasilan dalam kegiatan kultur jaringan ditentukan salah satunya oleh media. Media dapat dilengkapi dengan zat organik tambahan seperti ragi. Ragi merupakan salah satu bahan organik yang harganya relatif murah serta mengandung asam-asam amino, peptida dan vitamin yang sangat bermanfaat bagi pertumbuhan planlet. Menurut Hendaryono dan Wijayani (1994), asam amino berperan penting untuk pertumbuhan dan diferensiasi kalus. Oleh karena itu, untuk menunjang pertumbuhan dan diferensiasi kalus terbaik pada eksplan manggis perlu ditambahkan ragi pada medianya.

$$
\text { Hasil penelitian Damiska, }
$$

Wulandari dan Darwati (2015), yang menambahkan ragi sebanyak $9 \%$ menghasilkan jumlah tunas terbanyak pada eksplan manggis, hal ini disebabkan karena ragi memiliki kandungan asam amino dan protein yang tinggi sehingga baik untuk pertumbuhan dan perkembangan tanaman.

Penelitian ini bertujuan untuk mengetahui pengaruh penggunaan berbagai konsentrasi ragi terhadap pertumbuhan subkultur jaringan manggis (Garcinia mangostana L.) secara In-Vitro.

\section{METODOLOGI PENELITIAN}

\section{Tempat dan Waktu}

Penelitian ini dilaksanakan di Laboratorium Bioteknologi Tanaman Fakultas Pertanian Universitas Islam Riau Pekanbaru. Penelitian dilaksanakan selama empat bulan dari bulan September sampai dengan Desember 2015.

\section{Bahan dan Alat}

Bahan yang digunakan dalam penelitian ini adalah eksplan manggis berumur dua bulan (hasil inisiasi dari tim laboratorium bioteknologi UIR), bahan kimia media murashige-skoog, aquades steril, alkohol, tepung agar, glukosa, arang aktif, ragi, sunlight, twin, fungisida, bayclin, kertas tisu, kertas label, dan bahan-bahan lain yang mendukung penelitian ini.

Alat yang digunakan dalam penelitian ini adalah laminar air flow cabinet, autoklaf, timbangan analitik, stirer, erlenmeyer, gelas ukur, gelas piala, petridish, jarum injeksi, pipet, pengaduk kaca, pinset, scarpel, lampu spritus, hand sprayer, pisau, pH meter, botol kultur, kompor gas, lemari penyimpan bahan kimia, tabung reaksi, labu ukur, gunting, plastik, karet, aluminium foil, rak kultur, kulkas, ember plastik, alat tulis dan perlengkapan pencucian.

\section{Metode Penelitian}

Rancangan yang digunakan dalam penelitian ini adalah rancangan acak lengkap (RAL) non faktorial yaitu pemberian berbagai konsentrasi ragi (Faktor R) dengan 4 taraf perlakuan dan 3 kali ulangan. Dengan demikian penelitian ini terdiri dari 12 unit percobaan. Setiap unit percobaan terdiri dari 1 botol kultur yang masing-masing berisi 2 eksplan. 
Adapun perlakuannya adalah : R0 (Tanpa pemberian ragi), R1 (Pemberian ragi 4,5 $\%$ ), R2 (Pemberian ragi $9 \%$, R3 (Pemberian ragi 13,5\%).

\section{HASIL DAN PEMBAHASAN}

Umur Muncul Tunas (Hari)

Data hasil pengamatan terhadap parameter umur muncul tunas eksplan manggis setelah dilakukan analisis sidik ragam (Lampiran 5), menunjukkan bahwa pemberian ragi tidak berpengaruh nyata terhadap umur muncul tunas eksplan manggis, dan rerata umur muncul tunas eksplan mangis dapat dilihat pada Tabel 4.

Tabel 1. Rerata Umur Muncul Tunas Eksplan Manggis dengan Pemberian Berbagai Konsentrasi Ragi.

\begin{tabular}{lc}
\hline Perlakuan & Rerata (Hari) \\
\hline R0 (0\%) & 11,67 \\
R1 (4,5\%) & 12,00 \\
R2 (9\%) & 10,67 \\
R3 (13,5\%) & 11,00 \\
\hline \multicolumn{2}{c}{$\mathrm{KK}=12,18$} \\
\hline
\end{tabular}

Berdasarkan Tabel 4 dapat dilihat bahwa pemberian ragi tidak memberikan pengaruh yang nyata terhadap umur muncul tunas eksplan manggis, meskipun diberikan dengan konsentrasi yang berbeda-beda. Hal ini dikarenakan ragi tidak mengandung hormon atau zat pengatur tumbuh yang dapat merangsang pertumbuhan tunas eksplan dalam kultur jaringan, tetapi ragi lebih berfungsi memperbaiki pertumbuhan jumlah tunas, panjang tunas, serta berat planlet karena didalam ragi terdapat kandungan asamasam amino dan protein yang tinggi.

Hasil penelitian ini sejalan dengan penelitian yang dilakukan Maysarah, Wulandari dan Darwati (2012) yang menjelaskan bahwa ragi tidak dapat mempercepat umur muncul tunas pada eksplan manggis, tetapi ragi dapat memperbaiki pertumbuhan kalus dan tunas karena ragi merupakan sumber nitrogen yang berperan dalam proses fisiologis seperti pembentukan protein, asam nukleat, dan koenzim. Protein merupakan penyusun utama protoplasma yang fungsinya dapat membantu proses pertumbuhan dan differensiasi sel.

Pemberian ragi tidak memberikan pengaruh yang nyata terhadap umur muncul tunas eksplan manggis. Hal ini disebabkan, umur muncul tunas manggis pada semua perlakuan berlangsung dengan waktu yang bervariasi, kemunculan tunas yang bervariasi disebabkan karena ragi tidak mengandung zat pengatur tumbuh yang dapat mempercepat proses kemunculan tunas manggis. Na'im (2005) juga menyatakan kemunculan tunas yang bervariasi disebabkan oleh tanaman induk, dimana kemungkinan kecepatan penyerapan unsur hara maupun kandungan hormon endogen setiap jaringan tanaman yang berbeda. Kemunculan tunas yang bervariasi juga disebabkan oleh media tumbuh tanaman manggis, karena menurut Hendayono dan Wijayani (1994), media yang biasa digunakan dalam budidaya tanaman berkayu seperti manggis yaitu menggunakan media standar WPM (Woody Plant Medium), sedangkan dalam penelitian media yang digunakan adalah media MS (Murashige and Skoog).

Meskipun umur muncul tunas manggis tidak memberikan pengaruh yang nyata, namun umur muncul tunas manggis yang lebih cepat terdapat pada perlakuan R2 (pemberian ragi dengan konsentrasi $9 \%$ ) dengan rerata umur muncul tunas yaitu 10,67 hari setelah tanam, disusul 
dengan perlakuan $\mathrm{R} 3$ (pemberian ragi dengan konsentrasi $13,5 \%$ ) dengan rerata umur muncul tunas yaitu 11,00 hari setelah tanam, perlakuan Ro (tanpa pemberian ragi) dengan rerata umur muncul tunas yaitu 11,67 hari setelah tanam, perlakuan $\mathrm{R} 1$ (pemberian ragi dengan konsentrasi $4,5 \%$ ) dengan rerata umur muncul tunas yaitu 12,00 hari setelah tanam.

\section{Jumlah Tunas (Tunas)}

Data hasil pengamatan terhadap parameter jumlah tunas eksplan manggis setelah dilakukan analisis sidik ragam (Lampiran 6), menunjukkan bahwa pemberian berbagai konsentrasi ragi berpengaruh nyata terhadap jumlah tunas eksplan manggis, dapat dilihat dari hasil uji lanjut Beda Nyata Jujur (BNJ) pada taraf $5 \%$ pada Tabel 5 .

\section{Tabel 2. Rerata Jumlah Tunas Eksplan Manggis dengan Pemberian Berbagai Konsentrasi Ragi.}

\begin{tabular}{cc}
\hline Perlakuan & Rerata (Tunas) \\
\hline R0 $(0 \%)$ & $1,17 \mathrm{~b}$ \\
R1 $(4,5 \%)$ & $1,33 \mathrm{~b}$ \\
R2 $(9 \%)$ & $2,50 \mathrm{a}$ \\
R3 $(13,5 \%)$ & $1,67 \mathrm{ab}$ \\
\hline KK $=25,98$ & BNJ R $=1,01$
\end{tabular}

Angka-angka pada baris dan kolom yang diikuti huruf kecil yang sama tidak berbeda nyata menurut uji lanjut beda nyata jujur (BNJ) pada taraf $5 \%$.

Pemberian berbagai konsentrasi ragi memberikan pengaruh yang nyata terhadap jumlah tunas eksplan manggis, hal ini dikarenakan ragi memiliki kandungan asam amino dan protein yang tinggi yang bisa mempercepat proses differensiasi sel. Pengamatan jumlah tunas terbanyak terdapat pada perlakuan $\mathrm{R} 2$ (pemberian ragi dengan konsentrasi $9 \%$ ) dengan rerata jumlah tunas yaitu 2,50 tunas, perlakuan ini tidak berbeda nyata dengan perlakuan $\mathrm{R} 3$ (pemberian ragi dengan konsentrasi $13,5 \%$ ) dengan rerata jumlah tunas yaitu 1,67 tunas, tetapi berbeda nyata dengan perlakuan yang lain yaitu perlakuan $\mathrm{R} 1$ (pemberian ragi dengan konsentrasi $4,5 \%$ ) dengan rerata jumlah tunas yaitu 1,33 tunas, dan perlakuan R0 (tanpa pemberian ragi) dengan rerata jumlah tunas yaitu 1,17 tunas.

Pengamatan pemberian ragi terbaik terhadap jumlah tunas terdapat pada perlakuan $\mathrm{R} 2$ (pemberian ragi dengan konsentrasi 9\%) dengan rerata jumlah tunas yaitu 2,50 tunas, hal ini dikarenakan kandungan asam amino dan protein dalam ragi mampu mempercepat proses differensiasi sel, sehingga akan semakin banyak tunas-tunas baru yang terbentuk dan jumlahnya menjadi lebih banyak. Menurut Safitri, Wulandari dan Darwati (2013), penambahan beberapa konsentrasi ragi berpengaruh terhadap multiplikasi tunas manggis.

Rerata jumlah tunas terendah terdapat pada perlakuan Ro (tanpa pemberian ragi) yaitu 1,17 tunas. Dari hasil pengamatan, tanpa pemberian ragi (R0) pada eksplan manggis hanya menghasilkan satu tunas, sedangkan dengan pemberian berbagai konsentrasi ragi dapat menghasilkan lebih dari satu tunas. Dari pengamatan ini terlihat bahwa peran ragi dapat memperbanyak jumlah tunas pada eksplan manggis, karena didalam ragi terdapat nitrogen organik yang mana fungsi nitrogen terhadap pertumbuhan tanaman adalah dapat memperbaiki pertumbuhan vegetatif tanaman khususnya pertumbuhan jaringan tanaman.

Bila konsentrasi ragi dinaikkan menjadi $13,5 \%$ (R3) terjadi penurunan jumlah tunas, demikian pula bila konsentrasi ragi dibawah $9 \%$ seperti pada 
perlakuan R1 (4,5\%) juga terjadi penurunan jumlah tunas, hal ini menjelaskan bahwa ragi harus diberikan dengan konsentrasi yang tepat sehingga pertumbuhan jumlah tunas lebih optimal.

Hasil penelitian ini jika

dibandingkan dengan penelitian sebelumnya maka didapat kesimpulan yang sejalan dengan penelitian yang telah dilakukan oleh Damiska et al (2015) yang menjelaskan, penambahan ragi dengan konsentrasi $9 \%$ dapat mempengaruhi pertambahan jumlah tunas manggis, hal ini disebabkan ragi mempunyai kandungan nitrogen, serta vitamin yang lengkap yaitu vitamin A, B1, dan C sehingga pertumbuhan tunas dapat terjadi dengan baik, serta resiko keracunan juga lebih rendah. Kegunaan nitrogen bagi tanaman mampu menyuburkan tanaman sebab unsur $\mathrm{N}$ dapat membentuk protein yang banyak terdapat pada sel yang masih hidup atau pada bagian yang sedang aktif tumbuh terutama untuk pertumbuhan vegetatif tanaman, sehingga bila diberikan pada media subkultur tanaman manggis mampu meningkatkan jumlah tunas tanaman manggis.

\section{Panjang Tunas (cm)}

Data hasil pengamatan terhadap panjang tunas eksplan manggis setelah dilakukan analisis sidik ragam (Lampiran 7), menunjukkan bahwa pemberian ragi berpengaruh nyata terhadap panjang tunas eksplan manggis, dapat dilihat dari hasil uji lanjut Beda Nyata Jujur (BNJ) pada taraf $5 \%$ pada Tabel 6 .

Tabel 3. Rerata Panjang Tunas Eksplan Manggis dengan Pemberian Berbagai Konsentrasi Ragi.

\begin{tabular}{cc}
\hline Perlakuan & Rerata $(\mathrm{cm})$ \\
\hline R0 $(0 \%)$ & $1,62 \mathrm{~b}$ \\
R1 $(4,5 \%)$ & $1,90 \mathrm{~b}$ \\
R2 $(9 \%)$ & $2,78 \mathrm{a}$ \\
R3 $(13,5 \%)$ & $1,83 \mathrm{~b}$ \\
\hline $\mathrm{KK}=9,60$ & BNJ R $=0,46$ \\
\hline
\end{tabular}

Angka-angka pada baris dan kolom yang diikuti huruf kecil yang sama tidak berbeda nyata menurut uji lanjut beda nyata jujur (BNJ) pada taraf 5\%.

Berdasarkan Tabel 6 dapat dilihat bahwa pemberian berbagai konsentrasi ragi memberikan pengaruh yang nyata terhadap panjang tunas eksplan manggis, hal ini dikarenakan ragi memiliki kandungan nitrogen, vitamin, dan senyawa karbon yang berperan dalam proses fisiologis tanaman. Pengamatan panjang tunas terbaik terdapat pada perlakuan $\mathrm{R} 2$ (pemberian ragi dengan konsentrasi $9 \%$ ) dengan rerata panjang tunas yaitu $2,78 \mathrm{~cm}$, perlakuan $\mathrm{R} 2$ berbeda nyata dengan semua perlakuan yaitu perlakuan $\mathrm{R} 3$ (pemberian ragi dengan konsentrasi $13,5 \%$ ) dengan rerata panjang tunas yaitu $1,83 \mathrm{~cm}$, perlakuan R1 (pemberian ragi dengan konsentrasi $4,5 \%$ ) dengan rerata panjang tunas yaitu $1,90 \mathrm{~cm}$, dan perlakuan R0 (tanpa pemberian ragi) dengan rerata panjang tunas yaitu $1,62 \mathrm{~cm}$.

Pengamatan pemberian ragi terbaik terhadap panjang tunas terdapat pada perlakuan R2 (pemberian ragi dengan konsentrasi 9\%) dengan rerata panjang tunas yaitu $2,78 \mathrm{~cm}$, hal ini dikarenakan ragi memiliki kandungan nitrogen, vitamin, dan senyawa karbon yang berperan dalam proses fisiologis tanaman, seperti pembentukan protein, asam nukleat dan koenzim. Widiastoety dan Kartikaningrum (2003) juga menjelaskan, nitrogen merupakan komponen penyusun klorofil, protein, asam nukleat, dan beberapa substansi penting lainnya yang dibutuhkan untuk pembentukan protoplasma dan berfungsi untuk memperbaiki pertumbuhan dan perkembangan tanaman, yang mana 
kandungan klorofil dapat meningkatkan proses fotosintesis, sehingga fotosintat yang dihasilkan semakin tinggi. Akibat fotosintat yang tinggi, maka terjadi peningkatan tinggi planlet dan luas daun.

Rerata panjang tunas terendah terdapat pada perlakuan R0 (tanpa pemberian ragi) yaitu $1,62 \mathrm{~cm}$. Dari hasil pengamatan, tanpa pemberian ragi ( $R 0)$ eksplan manggis lebih sedikit mengalami pertambahan panjang tunas dibandingkan dengan pemberian berbagai konsentrasi ragi, hal ini dikarenakan dalam proses multiplikasi tunas ragi diperlukan dalam pembentukan protein, asam nukleat dan koenzim sehingga mampu memperbanyak tunas, sementara pada perlakuan R0 tidak diberikan ragi. Dari pengamatan ini terlihat bahwa peran ragi dapat mempercepat pertumbuhan panjang tunas pada eksplan manggis.

Bila konsentrasi ragi dinaikkan menjadi $13,5 \%$ (R3) terjadi penurunan panjang tunas, demikian pula bila konsentrasi ragi dibawah $9 \%$ seperti pada perlakuan R1 (4,5\%) juga terjadi penurunan panjang tunas, hal ini menjelaskan bahwa ragi harus diberikan dengan konsentrasi yang tepat sehingga pertumbuhan panjang tunas lebih optimal.

Hasil penelitian ini jika dibandingkan dengan penelitian yang dilakukan Safitri et al (2013), maka didapat kesimpulan yang sejalan yang menjelaskan bahwa penambahan ragi memberikan pengaruh yang nyata terhadap panjang tunas eksplan manggis pada konsentrasi $8 \%$.

\section{Berat Planlet (mg)}

Data hasil pengamatan terhadap berat planlet eksplan manggis setelah dilakukan analisis sidik ragam (Lampiran 8), menunjukkan bahwa pemberian ragi berpengaruh nyata terhadap berat planlet eksplan manggis, dapat dilihat dari hasil uji lanjut Beda Nyata Jujur (BNJ) pada taraf $5 \%$ pada Tabel 7 .

\section{Tabel 4. Rerata Berat Planlet Eksplan Manggis dengan Pemberian Berbagai Konsentrasi Ragi.}

\begin{tabular}{lc}
\hline Perlakuan & Rerata $(\mathrm{cm})$ \\
\hline R0 $(0 \%)$ & $0,12 \mathrm{~b}$ \\
R1 $(4,5 \%)$ & $0,18 \mathrm{ab}$ \\
R2 $(9 \%)$ & $0,25 \mathrm{a}$ \\
R3 $(13,5 \%)$ & $0,20 \mathrm{ab}$ \\
\hline KK $=21,77$ & BNJ R $=0,10$
\end{tabular}

Angka-angka pada baris dan kolom yang diikuti huruf kecil yang sama tidak berbeda nyata menurut uji lanjut beda nyata jujur (BNJ) pada taraf $5 \%$.

Berdasarkan Tabel 7 dapat dilihat bahwa pemberian ragi memberikan pengaruh yang nyata terhadap berat planlet eksplan manggis. Pengamatan berat planlet terbaik terdapat pada perlakuan R2 (pemberian ragi dengan konsentrasi $9 \%$ ) dengan rerata berat planlet yaitu 0,25 mg. Hasil uji lanjut Beda Nyata Jujur (BNJ) pada taraf 5\%, perlakuan R2 tidak berbeda nyata dengan perlakuan yaitu perlakuan R3 (pemberian ragi dengan konsentrasi $13,5 \%$ ) dengan rerata berat planlet yaitu $0,20 \mathrm{mg}$, dan perlakuan $\mathrm{R} 1$ (pemberian ragi dengan konsentrasi $4,5 \%$ ) dengan rerata berat planlet yaitu $0,18 \mathrm{mg}$, namun berbeda nyata dengan perlakuan R0 (tanpa pemberian ragi ) dengan rerata berat planlet yaitu $0,12 \mathrm{mg}$.

Perlakuan R2 (pemberian ragi konsentrasi 9\%) menghasilkan berat planlet terbaik, hal ini dikarenakan ragi memiliki kandungan nitrogen tinggi yang berperan dalam meningkatkan pertumbuhan vegetatif serta sebagai sumber energi dalam proses penyerapan nutrisi sehingga dengan optimalnya pemberian nutrisi tentu akan meningkatkan biomassa dan berat planlet. Secara keseluruhan jika dilihat dari 
parameter pengamatan sebelumnya terutama jumlah tunas dan panjang tunas, yang mana perlakuan terbaik terdapat pada R2 (pemberian ragi dengan konsentrasi 9\%), sehingga untuk pengamatan berat planlet terbaik juga terdapat pada perlakuan R2. Hal ini juga didukung oleh pendapat Patel dan Shrama (1997), yang menjelaskan bahwa nitrogen yang terkandung dalam ragi berpengaruh nyata terhadap peningkatan luas daun, yang mana nitrogen merupakan salah satu hara makro penyusun asam amino, klorofil dan senyawa lainnya dalam proses metabolisme. Kandungan klorofil yang tinggi dapat meningkatkan proses fotosintesis, sehingga fotosintat yang dihasilkan semakin tinggi, akibat fotosintat yang tinggi maka terjadi peningkatan tinggi planlet, luas daun, jumlah akar dan diameter batang, akibatnya berat planlet yang dihasilkan juga meningkat.

Parameter pengamatan berat planlet terendah terdapat pada perlakuan R0 (tanpa pemberian ragi) dikarenakan media tanpa pemberian ragi, kandungan hara yang diserap tanaman manggis lebih rendah daripada media yang ditambahkan dengan ragi. Hal ini karena ragi memiliki kandungan alamiah kompleks yang diperoleh dari hasil samping dalam proses fermentasi suatu minuman dengan jasad renik khamir. Sel khamir mempunyai struktur yang terdiri atas membran sel, kapsul, sitoplasma, sentosum, sentrokromatin, nukleus vakuola dan granula, dan diyakini mengandung zat hara untuk pertumbuhan tanaman (Lindegren, 1952 dalam Widiastoety dan Kartikaningrum, 2003).

\section{KESIMPULAN}

Berdasarkan hasil penelitian dapat disimpulkan bahwa penggunaan berbagai konsentrasi ragi berpengaruh nyata terhadap parameter jumlah tunas (2,5 tunas), panjang tunas $(2,78 \mathrm{~cm})$, berat planlet $(0,25 \mathrm{mg})$ dengan perlakuan terbaik terdapat pada $\mathrm{R} 2$ (pemberian ragi dengan konsentrasi $9 \%$ ), namun konsentrasi ragi tidak mempengaruhi parameter umur mucul tunas manggis (Garcinia mangostana L.) secara In-vitro.

\section{SARAN}

Berdasarkan penelitian diatas, untuk mendapatkan pertumbuhan eksplan manggis (Garcinia mangostana L.) yang optimal, maka disarankan dengan pemberian konsentrasi ragi $9 \%$.

\section{DAFTAR PUSTAKA}

Damiska S, Wulandari R S, Darwati $\mathrm{H}$. 2015. Penambahan Ragi dan Ekstrak Biji Jagung terhadap Pertumbuhan Tunas Manggis Secara In-Vitro. J Hutan Lestari 3(1): 35-42.

Hendaryono D P S dan Wijayani A. 1994. Teknik Kultur Jaringan, Pengenalan dan petunjuk Perbanyakan Tanaman Secara Vegetatif Modern. Kanisius. Jogjakarta.

Lindegren J. 1952. The yeast dalam Wilson C L and W E Loomis. 1962. Botany $3 \mathrm{~h}$ ed. Holt, Reinchart and Winston Inc., New York 108-110.

Maysarah, Wulandari R S dan Darwati $\mathrm{H}$. 2012. Pertumbuhan Eksplan Manggis (Garcinia mangostana L) Secara In-Vitro dengan Air Kelapa, Ekstrak Tauge, dan Ragi. J Hutan Lestari 1(1).

Na'im, Risqie N. 2005. Pengaruh NAA dan Kinetin pada Eksplan Tunas Biji Ulin (Eusideroxylon zwageri, T.et.B) dengan Sistem Kultur Jaringan. Fakultas Kehutanan, Untan.

Patel A J \& G C Shrama. 1997. Nitrogen release characteristic soil controlled release during four months soil incubation. J Amer. Soc. Hort. Sci. 103 (2): 364-366.

Pitojo S \& Pusita H N. 2010. Budidaya Manggis. Aneka Ilmu. Semarang.

Safitri R R E, Wulandari R S dan Darwati H. 2013. Penambahan Ragi Terhadap Multiplikasi Subkultur Tunas Manggis (Garcinia mangostana L) Secara In-Vitro. J Hutan Lestari 1(3).

Widiastoety D dan Kartikaningum S. 2003. Pemanfaatan Ekstrak Ragi dalam Kultur In-Vitro Planlet Media Anggrek. J Hort. 13(2): 82-86 
